\title{
The impact of each of the essential oils of marjoram and lemon grass in conjunction with gamma irradiation against the Greater Wax Moth, Galleria Mellonella
}

\author{
Hussein F. Mohamed ${ }^{(1)}$, Samira E.M. El-Naggar ${ }^{(1)}$, Nehad M. Elbarky ${ }^{(2)}$, \\ Abdelwahab A. Ibrahim ${ }^{(2)}$, Marwa S. Salama ${ }^{(1)}$ \\ ${ }^{\text {I} B i o l o g i c a l ~ A p p l i c a t i o n s ~ D e p a r t m e n t, N u c l e a r ~ R e s e a r c h ~ C e n t e r, ~ A t o m i c ~ E n e r g y ~ A u t h o r i t y, ~ C a i r o, ~ E g y p t . ~}$ \\ ${ }^{2}$ Entomology Department, Faculty of Science, Banha University, Cairo, Egypt.
}

\begin{abstract}
:
Objective: To evaluate the larvicidal activity of essential oils derived from two essential plants and / or gamma irradiation against early fourth instar larvae of the greater wax moth (GWM), Galleria mellonella L. was investigated.

Methods: The oil of two plants were tested namely; Marjoram, Origanum majorana and Lemon Grass, Cymbopogon proximus were tested. To evaluate the relative efficacies of these materials as alternative control agent against GWM. The two essential oils were evaluated further for the determination of their LC10, LC50 and LC90 values based on Probit analysis, five of gamma irradiation doses (100,150,200,250 and 300 Gy) and the combined effect of them and essential oil were tested.

Results: Comparing the estimated LC10, LC50, LC90 values of present investigation of mentioned essential oils indicated that essential oils of Origanum majorana is more toxic to G. mellonella than the other essential oil of Cymbopogon proximus, then were selected in combined with the dose of $100 \mathrm{~Gy}$ in the shared experience. It also found that the percentage of pupation, emergence and sex ratio decreased with increasing concentration of both extracts

- The lack of the number of eggs and the percentage of hatched eggs increase with the increase the radiation dose used from 100 Gy to 300 Gy

-Also found that the percentage of larval mortality increases in the case of combined treatment of radiation and aromatic oils of the two plants than in the case of both of them solo. The percentages of pupation and emergence less in the case of combined treatment, but increased in the case of sex ratio

Conclusion: it can be concluded that the insects varied in their susceptibility to various essential oils that probably referring to insecticidal ability of their active constituents
\end{abstract}

Key Words: Gamma Radiation / Essential oils / Galleria mellonella / Larval mortality

\section{Introduction}

The greater wax moth, Galleria mellonella L., is a major pest of the honey bee, Apis mellifera L. It feeds on wax and pollen stored in combs of active honey bee colonies (Milan, 1970).

Wax moths are serious pests of beeswax worldwide. Greater wax moth (GWM), Galleria mellonella L., and lesser wax moth, Acheroia gresilla L., are known to be harmful to deposited and stored beeswax. GWM causes the greatest damage in apiaries which lead to financial losses every year, beside damaging wax combs by larval feeding, and destroying frames and wooden parts in the hive. Adult wax moths and larvae can also transfer pathogens of serious bee diseases, e.g. foulbrood. However, in colonies infested with this disease, feces of wax moth contain large amounts of spores of the causative bacteria, Paenibacillus larvae (Charrière and Imdorf, 1997 and Owayss and Abd-Elgayed, 2007).

Possibilities for controlling wax moth including some manipulations in the hive and other treatments to stored combs i.e. technical, physical, biological and chemical methods e.g. sulphur fumigation, acetic and formic acids evaporation and applying paradichlorobenzene are practiced (Calderone, 2000 and Owayss and Abd-Elgayed, 2007). Although the use of these chemicals is somewhat easy and effective, some precautions of safety and contamination of bee products are considered. Also, some of these materials seemed to be ineffective against eggs of the wax moth (Fraser, 1997 and Owayss and Abd-Elgayed, 2007).

The environmental problems caused by overuse of pesticides have been the matter of concern for both scientists and public in recent years. The extensive use of the synthetic insecticides lead to the biological imbalance due to the destruction of beneficial species such as parasites and predators of the pests beside the destruction of pollinating insects such as honey bees. Natural products are an excellent alternative to synthetic pesticides as a means to reduce negative impacts to human health and the environment (Arnason et al., 1989; Kwon et al., 1996; Ahn et al., 1997 and Koul et al., 2008). Natural products of plants and plant derivatives are 
alternative agent to currently use for insect control because they constitute rich sources of bioactive chemicals. They are often active against insect species. They are biodegradable to non-toxic products. Additionally, plantderived materials are found to be highly effective against insecticide resistant insect pests (Arnason et al., 1989; Kwon et al., 1996 and Ahn et al., 1997), so that many investigators initiated a large screening efforts poisonous effects to use them as insecticides (Khmabay et al., 2002; El-Shazly and Hussien, 2004; Prowse et al., 2006 ; Malarvannan and Subashini, 2007 and Khalaf et al,. 2009).

Irradiation techniques seem to offer solutions that are desirable in many aspects, contributing that this treatment should eventually prove to be cheaper, safer and more reliable than chemical control. Irradiation shortens life span of insects (Baxter and Blair, 1969). According to (Knipling, 1955), insect exposure to ionizing radiation causes sterilization through induction of dominates lethal mutation in the genetic structure of organisms. This technique to be successful control device for suppressing and combating many lepidopteraus insect pests, including Galleria mellonella has been studied (Ibrahim, 1981; EL- kady et al., 1983; ELNaggar et al., 1984, 1999 and Abd El -Hamid 2004).

The release of sterile males into the insect population in nature did not show a great success with Lepidoptera species, because they are highly resistant to irradiation (North and Holt, 1968) and La Chance et al., 1973). First $\left(F_{1}\right)$ and second $\left(F_{2}\right)$ filial generations, from treated insects, exhibited various degrees of sterility, including alternation in various developmental characteristics (Carpenter et al., 1986 and El-shall et al., 1997). With some species of Lepidoptera it will be desirable that females are totally sterile to ensure no addition of immature to the field population. Also, irradiated females could share matings with the males.

In recent years, searching for environmentally safe methods to control insect pests has been carried out using plant derivatives with significant insecticidal effects, which have been considered as new source of pesticides with negligible side effects on the environment (Balandrin et al., 1985). Several wild plant extracts or isolated active compounds have been shown to act as potent acute or chronic insecticides (Emara et al., 2002; Tripathy and Singh, 2005 and Moawad and Ebadah 2007). Antifeedant, (Salem et al., 2003; Shishir et al., 2004 and Erturk, 2006) and insect growth regulators (Abou El-Ghar et al., 1996) against a variety of insect species.

Some facts show that the use of synthetic chemicals to control insects and arthropods raises several obvious concerns related to environment and human health. So, there is a growing demand for alternative repellents or natural products. These products possess good efficacy and are environmentally friendly. Essential oils from plants belonging to several species have been extensively tested to assess their repellent properties as a valuable natural resource (Grad, 2010; Nerio et al., 2010).

Essential oils are complex mixtures isolated from aromatic plants which may possess antioxidant and anti-inflammatory activities of interest in thye food and cosmetic industries as well as in the human health field (Miguel, 2010).

In Nature, essential oils play an important role in the attraction of insects to promote the dispersion of pollens and seeds or to repel other ones. In addition, essential oils may also act as antibacterials, antivirals, antifungals, insecticides, herbicides, or have feeding deterrent effects against herbivores by reducing their appetite for such plants. Essential oils have also an important role in allelopathic communication between plants (Ibrahim et al., 2001 and Bakkali et al., 2008). The detection of some of these biological properties needed for the survival of plants has also been the base for searching similar properties for the combat of several microorganisms responsible for some infectious diseases in humans and animals. This search intends to respond to the increasing resistance of pathogenic microbes to antibiotics (Miguel, 2010). Recently, research in essential (volatile) oils has received increased attention from both industrial and academic circles due to a growing interest in green consumerism (Burt, 2004; Holley and Patel, 2005 and Busattaa et al., 2008).

Origanum majorana, The genus Origanum majorana L. is an aromatic, perennial, herbaceous plant belonging to the family Lamiaceae. The plant has been used as a flavouring and herbal spice from time immemorial. Steam distillation of leaves and flower heads yields a volatile oil, known in the trade as oil of Sweet marjoram, widely used in flavouring food and also in perfumery. Medicinally it is used in both Ayurveda and Yunani system to cure various human ailments. The plant is pungent, bitter, hot, stomachic, anthelmintic, alexipharmic, useful in diseases of the heart and blood, fevers, leucoderma and inflammation (Kirtikar and Basu, 1985). An infusion of the plant is used as a stimulant, sudorific, emmenagogue and galactagogue and also useful in asthma, hysteria and paralysis (Farooqi and Sreeramu, 2004; Leeja and Thoppil, 2007). An essential oil against several species of bacteria (Busattaa et al., 2008) Among several essential oils that may be useful as antimicrobial agents, marjoram oil (Origanum majorana L.) may have the greatest potential for use in industrial applications (Baratta et al., 1998; Daferera et al., 2000; Deans and Svoboda, 1990; Ezzeddine et al., 2001; Busattaa et al., 2008 and Ayaril et al., 2013).

Cymbopogon proximus, The genus Cymbopogon belongs to the family Poaceae and possesses more than 100 species in tropical countries, including Brazil. Of those species, approximately 56 are aromatic. A few of them should be given special attention for their wide use in folk medicine and high content of essential oils 
with quite varied purposes, such as therapeutic and cosmetic ( Lorenzi and Matos, 2002 ). Within this genus are Cymbopogon citratus (D.C.) Stapf. (lemongrass), native to India, known for producing an essential oil rich in citral (Ming et al.,1996) and Cymbopogon nardus (L.) Rendle (citronella), native to Ceylon, known for the repellent power of its essential oil rich in citronellal (Castro and Ramos, 2003). The use of essential oils from species of the genus Cymbopogon, such as C. citratus and C. nardus, for the control of foodborne pathogenic bacteria is an interesting alternative, since these plants have a high essential oil yield (Oliveira et al., 2011) are widely distributed in Brazilian territory, in addition to being easy to cultivate (Barwick et al., 2000; Lorenzi and Matos, 2002 and Brugnera et al., 2011). The n-hexane extract of Cymbopogon proximus Stapf (halfa barr) showed a potent antifungal effect against two of the toxigenic fungi, namely Fusarium verticillioides and Aspergillus flavus. Also, was superior to other extracts of the evaluated plant species in inhibiting the growth of Fusarium verticillioides and Aspergillus flavus and reducing the production of mycotoxins; fumonisin and aflatoxin (El-Assiuty et al., 2006a, b).

The use of gamma radiation and plant extract are the most promising new approaches for controlling this insect. The combined effects of gamma irradiation and bioinsecticides on Lepidopterous insects have been studied by several authors (Sallam et al., 1991; Mohamed, 2004; Mohamed et al., 2004; El-Nagar et al., 2004; El-Shall and Mohamed, 2005; Mohamed, 2006 and Mohamed, 2013).

The objective of this work is to evaluate the larvicidal activity of essential plant oils (marjoram and lemon grass) and / or gamma irradiation against early fourth instar larvae of the greater wax moth (GWM), Galleria mellonella L.

\section{Insect rearing technique}

\section{Materials And Methods}

The laboratory strain larvae of G. mellonella were reared on a semi-synthetic diet composed of grounded wheat fortified with Treacle (molasses) (we excluded bee honey because of its known anti-bacterial effect), glycerin, yeast and powdered milk at $28-30{ }^{\circ} \mathrm{C}$ and $65 \pm 5 \%$ R.H. Culture used in this study originated from eggs surface sterilized with formalin (10\%) vapour treatment as suggested by David et al. (1972). Emerged adults were collected and kept in similar empty glass containers (egg laying cages) provided with paper lids (egg laying substrate) to the glass container. Paper carrying the eggs were removed for egg collection and replaced by new ones.

\section{Source of irradiation}

The source of gamma radiation used during the present study was from a Cobalt $60\left({ }^{60} \mathrm{Co}\right)$ irradiator installed in the cyclotron project, Nuclear Research Center, Abu Zaabal, Egypt; the dose rate of irradiation source was 1 Gray/ second.

\section{Experimental technique}

3.1. Volatile oils

Two commercially available volatile oils were tested in this study. Marjoram oil (Origanum majorana Lamiaceae) and Lemon Grass Oil (Cymbopogon proximus Poaceae). The tested oils were purchased as pure oil (Branded in Egypt) from Pharaonic Company of medicinal and aromatic oils and Nabet Company. The oils were extracted from the dried plants by steam distillation.

\subsection{Biological studies}

Four different concentrations $(0.625 \%, 1.25 \%, 2.500 \%$ and $5.00 \%)$ of each of the tested essential oils were prepared from the stock solution by diluting with an acetone in volumetric flasks to give the necessary concentrations.

The contact toxicity of four different acetone concentrations of the two volatile oils has been tested in Petri dish $(10 \mathrm{~cm})$ each of them containing 10 larvae of insects. Filter paper disks (Whatman No. 1) were cut into the Petri dish $10 \mathrm{~cm}$ diameters. Filter papers were impregnated with series of concentrations of each essential oil. Concentrations used for essential oils of Origanum majorana and Cymbopogon proximus were $0.625,1.250,2.500$, and $5.00 \%$. Ten replicates were run for each concentration and control (Acetone as control, the filter paper was impregnanted with acetone only). After 24, 48, 72 and $96 \mathrm{~h}$ from the beginning of exposure, numbers of dead and alive larvae were counted. The 10\%, 50\% and 90\% lethal concentrations (LC10, LC50 and LC90) values were assessed by Probit analysis (Finney, 1971). The effect of sublethal concentrations (LC50) on some biological aspects of the treated stage and its subsequent developmental stages were determined. \% pupation, $\%$ Emergence, Sex ratio and $\%$ Survival were calculated. 


\subsection{Irradiation process}

Full-grown pupae of GWM (Parental male ; $\mathrm{P}_{1}$ ) were irradiated 24-48 h before adult emergence (male line and female line) with 3 substerilizing doses 100, 150, and $200 \mathrm{~Gy}$ and two sterilizing doses 250 and 300 Gy, in a $100 \mathrm{cc}$ plastic cup. The fecundity (No. of eggs laid/क), fertility (No. of eggs hatched) and \% of hatchability were determined. For this purpose, four crossing combination were set up as follows for each dose:

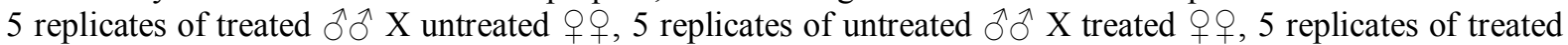

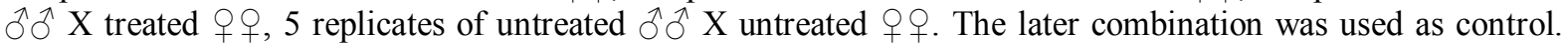
The daily-deposited eggs of irradiated and non-irradiated females were collected, counted, recorded and kept for calculating the percentage of eggs hatched.

\subsection{Combined effect of gamma irradiation and different essential oils on fecundity and fertility of Galleria mellonella}

Only one dose level of gamma irradiation from the previous doses was chosen (100Gy) to study the combined effect of gamma irradiation with the (Lc50) of different botanical essential oils on the Fecundity and fertility among $F_{1}$ generation.

To continue the $F_{1}$ generation for the male line, newly hatched larvae resulting from irradiated $\mathrm{P}_{1}$ males were kept in groups, in glass jars, and provided with a semi-synthetic diet. The contact toxicity of three acetone concentrations (Lc50) of the three volatile oils has been tested in Petri dish $(10 \mathrm{~cm})$ each of them containing 10 larvae of insects. Filter paper disks (Whatman No. 1) were cut into the Petri dish $10 \mathrm{~cm}$ diameters. Filter papers were impregnated with series of concentrations of each essential oil. Concentrations used for essential oils of Menth piperita, Pelargonium graveolens and Ocimum basilicum were 1.250, 2.50 and $0.625 \%$. Ten replicates were run for each concentration and control (Acetone as control, the filter paper was impregnanted with acetone only). Each treatment were transferred to a glass jar $(500 \mathrm{cc})$, furnished with a thin layer of sawdust to absorb excess humidity and covered with muslin fixed with a rubber band. Rearing was continued in the same way until the larvae reached the last larval instar, and then larvae were transferred individually to small plastic vials (10 cc) containing moistened sawdust for pupation. Newly formed pupae were collected and sexed, and each sex was kept separately in a plastic container with moistened sawdust and covered, as usual, with muslin cloth. For each treatment, the newly emerged males of the first generation $\left(F_{1}\right)$ of descendants from irradiated parental males were paired with newly emerged untreated females using all possible crosses between them in order to obtain the $F_{2}$ generation. The crossing scheme for this study is illustrated as follows:

$\mathrm{F}_{1}$ Crosses: (Normal male $\mathrm{x}$ Normal female) serve as a control

$F_{1}$ Male (male line) $x$ Normal female

[Normal male x $F_{1}$ Female (male line)]

The daily-deposited eggs of irradiated and non-irradiated females were collected, counted, recorded and kept for calculating the percentage of eggs hatched.

\section{Statistical analysis}

Data were analyzed using the Analysis of Variance (ANOVA) technique and the means were separated using Duncan s multiple range test $(\mathrm{P}>0.05)$ (Steel and Torrie, 1980).

\section{Results And Discussion}

The results of LC50 values of various essential oils are shown in Table 1. Results of this research showed that percentage of larval mortality was increased with the concentration and the time of exposure. In the other hand, toxicity depends on concentration, type of essential oil and exposure time. Figs. 1 and 2 shows that mortality was increased with increasing the concentration and exposure time in all cases. Essential oils of Origanum majorana at lowest concentration $(0.625 \%)$ caused $4 \%$ mortality in insect population after $24 \mathrm{~h}$ and compared to $100 \%$ mortality at the highest concentration (5\%) after 96h (Fig. 1). Lowest concentration of essential oil of Cymbopogon proximus at lowest concentration ( $0.625 \%$ ) caused, also, $4 \%$ mortality in insect population after $24 \mathrm{~h}$ and compared to $90 \%$ mortality at the highest concentration (5\%) after 96h (Fig. 2).

Khoso et al., (2011) studied the effects of various plant extracts (Akk, Eucalyptus, Dhatura, Neem ) on survival \& Development of Spodoptera litura (Fab), (Lepidoptera, Noctuidae). Survival percentage of each life stage was observed, and for 1 st instars larvae it was $55 \%, 70 \%, 78.50 \%, 81 \%$ on Neem, Dhatura, Akk, Eucalyptus and $85 \%$ on untreated spinach leaves was recorded. After passing 2nd, 3rd, 4th, 5th, 6th instars the larvae percentage turned into pupae was recorded as $10.50 \%, 22 \%, 23 \%, 30 \%$ on Neem, Akk, Dhatura, Eucalyptus and $44 \%$ in untreated spinach leaves. The adult survival percentage was recorded as $8.50 \%, 14 \%$, $22 \%, 31 \%$ on Neem, Dhatura, Eucalyptus, Akk and $31.50 \%$ on untreated spinach leaves. It is concluded that the neem leaf extract proved significantly effective against all life stages of S. litura. 
Table (1): The effect of Origanum majorana and Cymbopogon proximus volatile oils on the percentage larval mortality of the Greater wax moth, galleria mellonella

\begin{tabular}{|c|c|c|c|c|c|c|c|}
\hline \multirow{2}{*}{ Volatile oil } & \multirow{2}{*}{ 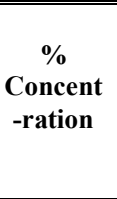 } & \multicolumn{4}{|c|}{$\%$ Larval mortality after $\ldots h \pm \mathrm{SE}$} & \multirow{2}{*}{$\begin{array}{c}\% \\
\text { Total larval mortality } \\
\text { in the end larval period }\end{array}$} & \multirow{2}{*}{$\begin{array}{c}\% \\
\text { Total larval } \\
\text { mortality in the end } \\
\text { larval period } \\
\text { (Deviation from } \\
\text { control) }\end{array}$} \\
\hline & & $24 \mathrm{~h}$ & $48 \mathrm{~h}$ & & $96 \mathrm{~h}$ & & \\
\hline Control & "--- & 00.00 & $1 \pm 1.000$ & $2 \pm 1.33$ & $6 \pm 2.212$ & $14 \pm 3.715$ & 000.00 \\
\hline Acetone & "--- & 00.00 & $3 \pm 1.529$ & $5 \pm 2.689$ & $13 \pm 3.961$ & $21 \pm 3.789$ & 150.00 \\
\hline \multirow{4}{*}{$\begin{array}{c}\text { Origanum } \\
\text { majorana }\end{array}$} & 0.625 & $04 \pm 2.212$ & $12 \pm 2.908$ & $26 \pm 6.869$ & $33 \pm 5.976$ & 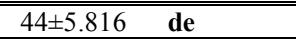 & 314.286 \\
\hline & 1.250 & $10 \pm 2.984$ & $30 \pm 6.836$ & $41 \pm 6.232$ & $44 \pm 6.004$ & $59 \pm 5.671$ & 421.429 \\
\hline & 2.500 & $77 \pm 8.178$ & $87 \pm 5.592$ & $87 \pm 5.592$ & $87 \pm 5.920$ & $89 \pm 4.336 \mathbf{a b}$ & 635.714 \\
\hline & 5.000 & $97 \pm 1.529$ & $97 \pm 1.529$ & $97 \pm 1.529$ & $100 \pm 0.000$ & $100 \pm 0.000 \mathbf{a}$ & 714.286 \\
\hline \multirow{4}{*}{$\begin{array}{c}\text { Cymbopogon } \\
\text { proximus }\end{array}$} & 0.625 & $04 \pm 2.212$ & $15 \pm 3.075$ & $21 \pm 3.789$ & $22 \pm 3.890$ & $26 \pm 4.525$ & 185.714 \\
\hline & 1.250 & $10 \pm 2.984$ & $23 \pm 6.511$ & $27 \pm 6.159$ & $27 \pm 6.158$ & $33 \pm 5.178$ & 235.714 \\
\hline & 2.500 & $54 \pm 7.185$ & $62 \pm 7.123$ & $69 \pm 7.224$ & $74 \pm 6.705$ & $81 \pm 7.526 \quad$ bc & 578.571 \\
\hline & 5.000 & $78 \pm 6.294$ & $83 \pm 3.961$ & $87 \pm 4.488$ & $90 \pm 2.984$ & $93 \pm 2.136 \mathbf{a b}$ & 664.286 \\
\hline
\end{tabular}

Means followed by the same letter in each column are not significantly different at $(p>0.05)$

Mohamed (2012) studied the effect of Plant extract (Neem) with the concentrations 0, 10,15,20,25, 50, 75 and $100 \mathrm{ppm}$ on the percentage of observed mortality and corrected mortality of the Greater wax moth, Galleria mellonella Zeller. The percentage observed mortality and the percentage corrected mortality were significantly increase by increasing the plant extract concentrations. The effect of plant extract (Neem) on the percentage larval mortality of G. mellonella after 5, 10, 15 and 20 days increase by increasing the period horizontally and the concentration vertically. The lowest increase was $7.78 \%$ from the control treatment after 5 days at the concentration $15 \mathrm{ppm}$, while, the highest larval mortality was $63.34 \%$ from the control treatment after 20 days at the concentration $20 \mathrm{ppm}$.

The essential oils of $\mathbf{C}$. glandulosa with concentration of $1.14 \%$ on Tribolium Castaneun showed powerful toxic and repellent effect, with very high mortality rate after $24 \mathrm{~h}(56,67 \%)$. The essential oil of $\mathbf{C}$. glandulosa at the highest concentration tested caused the death of $83.33 \%$ of the Tribolium Castaneun insects after $48 \mathrm{~h} .1 .14 \%$ concentration of $\mathbf{C}$. glandulosa oils was used, $56.67 \%$ of the insects died after $24 \mathrm{~h}$. After $48 \mathrm{~h}$, the most effective formulation was C.glandulosa with $83.33 \%$ mortality. After $96 \mathrm{~h}$, the oils of previously mentioned plants showed greatest toxicity $(96.67 \%$ mortality). In the case of Thymus serpyllum lower mortality was observed in the same concentration (1.14\%), and the percentage of died insects was $13.33 \%$ after $48 \mathrm{~h}$ and $96 \mathrm{~h}$. After $48 \mathrm{~h}$, the mortality rate of Origanum vulgare and Teucrium chameadrys was very low $6.66 \%$. Also, essential oils of these two plants produced a weak toxic effect, and the mortality rate was $10 \%$, after $96 \mathrm{~h}$. However, the formulations containing the essential oils of remaining plants produced zero mortality after $48 \mathrm{~h}$ and $96 \mathrm{~h}$. The lower concentration of essential oils of all nine plants examined was $0.02 \%$, but there was no mortality after 24h, 48h, and 96h (Popović et al., 2013).

The insecticidal activity of the volatile oils of Origanum majorana and Cymbopogon proximus was evaluated. On the basis of mortality percentages, it was found that they showed a promising insecticidal activity. The toxicity of the volatile oils of Origanum majorana and Cymbopogon proximus against the fourth instar larvae of G. mellonella exposed for 24, 36, 72 and 96 hours showed that the LC50s are $1.0166 \%$, and $1.7824 \%$, respectively (Table 2).

Comparison of the estimated LC50 values of essential oils (Table 2.) indicated that Origanium majorana essential oils is significantly more toxic to G. mellonella (1.0166) than other essential oil (Cymbopogon proximus) which were reported in this study (1.7824). Furthermore, Tables 2.1 and 2.2 indicates the preparation mortality of the two essential oils and comparison between actual and expected mortality among the five concentrations $0,0.625,1.25,2.50$ and $5 \%$. It shows that actual and expected mortality increase by increasing the concentration.

Table 2. Toxicity of Origanium majorana and Cymbopogon proximus essential oils against G. mellonella

\begin{tabular}{|c|c|c|c|c|c|}
\hline $\begin{array}{c}\text { Concentration } \\
\mathbf{\%}\end{array}$ & $\begin{array}{c}\text { No. of } \\
\text { Rep. }\end{array}$ & $\begin{array}{c}\text { Actual } \\
\text { mortality } \\
\mathbf{\%}\end{array}$ & $\begin{array}{c}\text { Expected } \\
\text { mortality } \\
\mathbf{\%}\end{array}$ & Deviation & Probability \\
\hline Control (0) & 100 & 14 & 15.046 & -1.046 & 0.1505 \\
\hline $\mathbf{0 . 6 2 5}$ & 100 & 44 & 37.632 & 6.368 & 0.3763 \\
\hline $\mathbf{1 . 2 5 0}$ & 100 & 59 & 66.423 & -7.423 & 0.6642 \\
\hline $\mathbf{2 . 5 0 0}$ & 100 & 89 & 89.493 & -0.493 & 0.8949 \\
\hline $\mathbf{5 . 0 0 0}$ & 100 & 100 & 98.277 & 1.723 & 0.9828 \\
\hline
\end{tabular}

$\mathrm{n}^{\mathrm{a}}:$ number of insect ${ }^{\mathrm{b}} 95 \%$ : Lower and upper fiducially limits are shown in parenthesis 
The impact of each of the essential oils of marjoram and lemon grass in conjunction with .....

Table 2.1. Preparation mortality of Origanium majorana essential oil (Chi - Sequared goodness of fit test)

\begin{tabular}{|c|c|c|c|c|c|}
\hline $\begin{array}{c}\text { Concentration } \\
\text { \% }\end{array}$ & $\begin{array}{c}\text { No. of } \\
\text { Rep. }\end{array}$ & $\begin{array}{c}\text { Actual } \\
\text { mortality } \\
\mathbf{\%}\end{array}$ & $\begin{array}{c}\text { Expected } \\
\text { mortality } \\
\mathbf{\%}\end{array}$ & Deviation & Probability \\
\hline Control (0) & 100 & 14 & 14.916 & -0.916 & 0.1492 \\
\hline $\mathbf{0 . 6 2 5}$ & 100 & 26 & 21.968 & 4.032 & 0.2197 \\
\hline $\mathbf{1 . 2 5 0}$ & 100 & 33 & 42.095 & -9.095 & 0.4209 \\
\hline $\mathbf{2 . 5 0 0}$ & 100 & 81 & 72.152 & 8.858 & 0.7215 \\
\hline $\mathbf{5 . 0 0 0}$ & 100 & 90 & 92.659 & -2.659 & 0.9266 \\
\hline
\end{tabular}

Chi-

Square $=6.0636$

Table 2.2. Preparation mortality of Cymbopogon proximus essential oil (Chi - Sequared goodness of fit test) Chi- Square $=9.3438$

\begin{tabular}{|c|c|c|c|c|c|c|c|c|}
\hline Essential oils & $\mathrm{n}^{\mathrm{a}}$ & $\mathrm{LC}_{10}$ & $\mathrm{LC}_{50}$ & $\mathbf{L C}_{90}$ & Slope & Df & $\begin{array}{c}\text { Chi- } \\
\text { square } \\
\left(\mathbf{X}^{2}\right)\end{array}$ & $\begin{array}{l}\text { Hetero- } \\
\text { geneity }\end{array}$ \\
\hline $\begin{array}{c}\text { Origanium } \\
\text { majorana }\end{array}$ & 100 & $\begin{array}{c}0.3752 \\
(0.0312-0.7152)\end{array}$ & $\begin{array}{c}1.0166 \\
(0.3818-1.5773)\end{array}$ & $\begin{array}{c}2.7548 \\
(1.8073-8.5533)\end{array}$ & $2.960 \pm 0.364$ & 2 & 6.0636 & 3.0318 \\
\hline $\begin{array}{l}\text { Cymbopogon } \\
\text { proximus }\end{array}$ & 100 & 0.6763 & 1.7824 & 4.6977 & $3.045 \pm 0.407$ & 2 & 9.3438 & 4.6719 \\
\hline
\end{tabular}

Table (3) indicates the effect of two volatile oils on larval stages and its subsequent developmental stages on the Greater wax moth, galleria mellonella. It shows that the percentage larval mortality, the percentage pupation, the percentage emergence, Sex ratio and the percentage survival to the two essential oils Origanum majorana and Cymbopogon proximus among the concentrations $0.625 \%, 1.250 \%, 2.500 \%$, $5.00 \%$, Control and Acetone.

The percentage larval mortality, increase by increasing the concentrations at the two volatile plant oils among all treatments when compared with the untreated control and the acetone.

The results in Table (3) illustrate that the two volatile oils treatment of the fourth instar larvae among the four concentrations induced a significantly decrease in the percentage of pupation by 56.00,41.00,11.00 and $00.00 \%$ respectively when compared with $86 \%$ to the untreated control in treatment with Origanum majorana. The concentrations 2.500 and $5.00 \%$ were more significantly decreased than the other concentrations 0.625 and $1.25 \%$.

In treatment with Cymbopogon proximus, the percentage pupation was more significantly decrease to 17.00 and $07.00 \%$ from the control treatment (86\%) at the two concentrations 2.500 and $5.00 \%$ respectively than the two other concentrations 0.625 and $1.25 \%$ (74.00 and 67.00\%).

Essential oils of Origanum majorana and Cymbopogon proximus (Table 2, 2.1 and 2.2) displayed considerable contact toxicity on larvae of G. mellonella especially, Origanum majorana (97 \% larval mortality at the concentration $5.00 \%$ from the first day. In previous investigations demonstrated that essential oils of Origanum

Table (3): The effect of Origanum majorana and Cymbopogon proximus volatile oils on some biological aspects of the Greater wax moth, Galleria mellonella

\begin{tabular}{|c|c|c|c|c|c|c|c|}
\hline \multirow[b]{2}{*}{ Essential oil } & \multirow{2}{*}{$\begin{array}{c}\% \\
\text { Concentration }\end{array}$} & \multirow{2}{*}{$\begin{array}{c}\% \\
\text { Larval mortality } \\
\pm \mathrm{SE}\end{array}$} & \multirow{2}{*}{$\begin{array}{c}\% \\
\text { Pupation } \\
\pm \text { SE } \\
\end{array}$} & \multirow{2}{*}{$\begin{array}{c}\% \\
\text { Emergence } \\
\pm \mathrm{SE} \\
\end{array}$} & \multicolumn{2}{|c|}{ Sex ratio } & \multirow{2}{*}{$\begin{array}{c}\% \\
\text { Survival } \\
\pm \mathrm{SE} \\
\end{array}$} \\
\hline & & & & & $\begin{array}{l}\text { Male } \\
\pm \text { SE }\end{array}$ & $\begin{array}{c}\text { Femal } \\
\mathrm{e}\end{array}$ & \\
\hline Control & ב-- & $14 \pm 3.715$ & $86 \pm 3.715 \mathrm{a}$ & $97.89 \pm 01.411 \mathbf{a}$ & $1.43 \pm 0.228 \mathrm{a}$ & 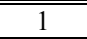 & $83 \pm 3.002 \mathbf{a}$ \\
\hline Acetone & "--- & $21 \pm 3.789$ & $79 \pm 3.789 \mathrm{a}$ & $95.39 \pm 01.897 \mathbf{a}$ & $1.69 \pm 0.208 \mathbf{a}$ & 1 & $75 \pm 3.075 \mathbf{a}$ \\
\hline \multirow{4}{*}{$\begin{array}{c}\text { Origanum } \\
\text { majorana }\end{array}$} & 0.625 & $44 \pm 5.816$ & $56 \pm 5.816 \quad$ cd & $97.50 \pm 02.502 \mathbf{a}$ & $1.03 \pm 0.248 \mathbf{a}$ & 1 & $54 \pm 5.211 \quad$ c \\
\hline & 1.250 & $59 \pm 5.671$ & $41 \pm 5.671$ & $96.67 \pm 03.335 \mathbf{a}$ & $0.92 \pm 0.394 \mathbf{a}$ & 1 & $40 \pm 5.967$ \\
\hline & 2.500 & $89 \pm 4.336 \mathbf{a b}$ & $11 \pm 4.336$ & $50.00 \pm 16.679$ b & $0.25 \pm 0.067 \quad \mathbf{b}$ & 1 & $11 \pm 4.336$ \\
\hline & 5.000 & $100 \pm 0.000 \mathbf{a}$ & $00 \pm 0.000$ & $38.33 \pm 14.508 \quad$ c & $0.10 \pm 0.067 \quad \mathbf{b}$ & 1 & $00 \pm 0.000$ \\
\hline \multirow{4}{*}{$\begin{array}{c}\text { Cymbopogon } \\
\text { proximus }\end{array}$} & 0.625 & $26 \pm 4.525$ & $74 \pm 4.525 \mathbf{a b}$ & $86.83 \pm 04.278 \mathbf{a}$ & $1.12 \pm 0.226 \mathbf{a}$ & 1 & $64 \pm 4.524$ b \\
\hline & 1.250 & $33 \pm 5.178$ & $67 \pm 5.178$ bc & $88.21 \pm 04.278 \mathbf{a}$ & $0.40 \pm 0.111 \quad$ b & 1 & $60 \pm 5.967 \mathbf{b}$ \\
\hline & 2.500 & $81 \pm 7.526 \quad$ b & $17 \pm 6.511$ & $50.00 \pm 16.678$ b & $0.80 \pm 0.396 \mathbf{a}$ & 1 & $17 \pm 6.511$ \\
\hline & 5.000 & $93 \pm 2.136 \mathbf{a}$ & $07 \pm 2.133$ & $50.00 \pm 16.678$ b & $0.10 \pm 0.100 \quad$ b & 1 & $06 \pm 2.212$ \\
\hline
\end{tabular}

$1-\mathrm{T} / \mathrm{C} \%=$ Treatment $/$ Control X100

2- Means followed by the same letter in each column are not significantly different at $(\mathrm{p}>0.05)$ 
majorana (LC50; 1.0166, Table, 2 nearly at the concentration $1.25 \%$, Tables, 1and 2.1 at the end of larval period), but, Cymbopogon proximus (LC50; 1.7824, Table, 2 between the concentrations 1.25 and 2.50 $\%$, Tables, 1 and 2.2).

Comparing the estimated LC50 values of present investigation with LC50 values of mentioned essential oils indicated that essential oils of Origanum majorana is more toxic to G. mellonella than the other essential oil of Cymbopogon proximus. Results of this investigation clearly illustrated that insects varied in their susceptibility to various essential oils that probably referring to insecticidal ability of their active constituents. These results agreement with Pavela (2005) tested thirty-four essential oils for insecticidal activity (fumigation or topical application) against larvae Spodoptera littoralis. Twenty essential oils applied by fumigation were highly toxic to the third instar of S. littoralis larvae. Two essential oils Nepeta cataria and Thuja occidentalis were highly toxic, with $\mathrm{LC} 50<=10.0 \mathrm{ml} / \mathrm{m} 3$. Five essential oils Salvia sclarea, Thymus mastichina, Origanum majorana, Pogostemon cablin and Mentha pulegium were toxic with LC50 between 10.1 and $20.01 \mathrm{ml} / \mathrm{m} 3$.

Twenty-three essential oils were highly toxic to the third instar of S.littoralis larvae after topical application. Eight essential oils Mentha citrata, N. cataria, S. sclarea, O. vulgare, O. compactum, Melissa officinalis, T. mastichina, and Lavandula angustifolia were highly toxic with LD50<=0.05 micro $1 /$ larvae. Abbasipour et al (2009) they reported that essential oils of Rosemarinus officinalis possess toxic effect in gaseous phase against adults of Tribolium castaneum (LC50 103.28 $\mu \mathrm{l} / \mathrm{L}$ air). LC50s values of peppermint oil against larvae and adults of the black carpet beetle were 1.093 and $1.673 \mathrm{ml} / 80 \mathrm{~cm}^{3}$, respectively, compared with $1.279 \mathrm{ml} / 80 \mathrm{~cm}^{3}$ and $1.799 \mathrm{ml} / 80 \mathrm{~cm}^{3}$ for the larvae and adults of cigarette beetle, respectively (Bakr et al,. 2010). The noticeable signification between the LC50 values of $\mathbf{T}$. castaneum and $\mathbf{C}$. maculatus can be of their differences in morphology, physiology, sensitivity and other factors. Results of this study suggested that essential oils of L. citrodora, R. officinalis, M. piperita and J. sabina plants are good choice for controlling this pest (Mahmoudv et al., 2011). Also, we need some additional studies for formulating and improving methods of application of them.

The obtained results in Table 3 Also, clearly demonstrate the treated fourth instar larvae of G. mellonella with four concentrations $(0.625 \%, 1.25 \%, 2.500 \%$ and $5.00 \%)$ of the two volatile oils. The percentage of adult emergence reduced to $97.50 \%, 96.67 \%, 50.00 \%$ and $38.33 \%$ respectively from the untreated control treatment when treated with Origanum majorana. Cymbopogon proximus reduced the percentage of adult emergence to $86.83 \%, 88.21 \%, 50.00 \%$ and $50.00 \%$ respectively from the untreated control treatment. In treatment with the two volatile oils (Table 3 ), the sex ratio significantly decreases by increasing the concentration at all treatments. Origanum majorana was more delayed effect than the other volatile oil observed at all. Also, the percentage survival has the same trend nearly.

These previous results are agreement with many authors among them Mohamed (2012) who studied the effect of Plant extract (Neem) with the concentrations 0, 10,15,20,25, 50, 75 and 100 ppm on the percentage of pupation, emergence and adult survival which shows that the percentage decreased among the three parameters by increasing the concentration, the percentage pupation decreased from $69.16 \%$ at the concentration $5 \mathrm{ppm}$ to $33.66 \%$ at the concentration $20 \mathrm{ppm}$. The percentage emergence decreased from $68.63 \%$ at the concentration $5 \mathrm{ppm}$ to $35.40 \%$ at the concentration $20 \mathrm{ppm}$. The percentage of adult survival decreased from $47.46 \%$ at the concentration $5 \mathrm{ppm}$ to $12.98 \%$ at the concentration $20 \mathrm{ppm}$.

Similar observation on the other plants extracts effect on several insect pests have been reported that The plant volatile essential oils isolated from Trachyspermum ammi, Anethum graveolens, Nigella sativa show insecticidal activity against T. castaneum (Chaubey, 2007), while the leaf essential oil of Melaleuca cajuputi had different insecticidal activity against Sitophilus zeamais and T. castaneum but 100\% repellency was only occurred in T. castaneum (Ko et al., 2009). The essential oil derived from Citrus peels possesses pesticidal activity against both insect pests T. castaneum and S. oryzae (Mishra et al., 2011). The effect of essential oil of Ocimum grattissimum leaves on S. zeamais was assessed for repellency and toxicity (Mishra et al., 2012).

Extract of leaves of Ocimum viride proved most effective in the control of Tribolium castaneum (Coleoptera: Tenebrionidae) and Sitophilus oryzae (Coleoptera: Curculionidae), followed by that of Chromolaena odorata. O. viride showed strong repellent activity and thus deterred the insects from feeding. It reduced survival of both insect pests to less than $25 \%$ after 10 days of treatment at concentrations of $0.1 \mathrm{mg} \mathrm{ml}^{-1}$ and above. The results show the potential of $\mathbf{O}$. viride and $\mathbf{C}$. odorata in the control of stored-product insects (Owusu, 2000).

Jain et al. (2005) reported the growth-inhibiting effect of four non-edible oils (NEOs) at 1\%, i.e. neem (Azadirachta indica), karanj (Pongamia pinnata), mahua (Madhuca indica [M. longifolia]) and eucalyptus (Eucalyptus rostrata), on castor semilooper, Achaea janata, was studied by feeding the larvae on treated castor leaves. 
All the NEOs effectively inhibited the growth of the test insect as manifested by prolonged larval, pupal and total life cycle duration, larval survival and normal adult emergence, adult longevity and growth index. The growth-inhibiting effect of the NEOs in descending order was neem oil $>$ karanj oil $>$ mahua oil $>$ eucalyptus oil.

Plant products especially in the form of essential oils having considerable potential as insecticidal compounds are gaining tremendous importance in recent years. The leaves essential oil of Eucalyptus globulus and Ocimum basilicum was significantly $(\mathrm{P}<0.05)$ repellent at very low concentration against the flour beetle and rice weevil and join a series of some other essential oils which have similar insecticidal effects on the management of pests and provides a scientific relation for their use in control of stored-grain insect pests (Hassanali et al., 1990; Bekele et al., 1996; Bouda et al., 2001 and Mishra et al., 2012).

Table 4 Illustrates the effect of gamma irradiation on the average number of eggs and the percentage of the egg hatch of the Greater wax moth, galleria mellonella at $0,100,150,200,250,300$ Gy of gamma radiation among the pairings normal male with normal female, treated male with normal female and normal male with treated female.

The average number of eggs and the percentage of the egg hatch were significantly decrease by increasing the concentration at all treatments when compared with the untreated control.

The highest decrease in the average number of eggs was at the mating (treated Male $\mathrm{x}$ Treated Female) among the three doses $200 \mathrm{~Gy}, 250 \mathrm{~Gy}$ and $300 \mathrm{~Gy}$, it was $00.00 \%$, at the three doses from the untreated control treatment. Also, the percentage of the egg hatch in table 4 was significantly decrease by increasing the concentration at all treatments when compared with the untreated control. The highest decrease in the percentage of the egg hatch was $0.00 \%$ from the untreated control treatment at the dose rates $200 \mathrm{~Gy}$ (Treated male X Treated female), 250 Gy (Treated male X Treated female) and 300 Gy among the three matings ( Treated male X Normal female, Normal male X Treated female and Treated male X Treated female).

Many authors agreement with us, Ibrahim et al., (1999) Studied the fecundity, egg hatch and mating of normal females of Agrotis ipsilon (Hufn.) crossed with males irradiated as full grown pupae with doses of 100 and 150 Gy of gamma radiation. The egg hatch of females was significantly reduced by increasing the radiation dose among $P_{1}$ and $F_{1}$ generations as compared with the control. Hofmeyr et al. (2004) reviewed the control of false codling moth, Cryptophlebia leucotreta, and the history of the sterile insect release technique. The fecundity (number of eggs produced) and fertility (number of eggs hatched) of irradiated false codling moth are progressively reduced with increasing doses of gamma radiation in the range 50 to $350 \mathrm{~Gy}$.

Tate et al. (2007) studied the Influence of gamma irradiation on female adults of the cactus moth, Cactoblastis cactorum (Berg). Inherited deleterious effects of gamma radiation were observed in the $F_{1}$ and $F_{2}$ generations. Fecundity and the daily egg laying pattern of irradiated and unirradiated females mated to irradiated males was not significantly different from untreated controls. Adverse effects of gamma radiation were observed in the percentage egg hatch and rate of development. Levels of sterility in the $P_{1}, F_{1}$ and $F_{2}$ generations were higher than that of untreated controls.

Aye et al. (2008) demonstrated the inhibitory effects of gamma irradiation on the devolpment and reproduction including egg hatch, Pupation, adult eclosion and oviposition of Plodia interpunctella. Failure of all these events increased with increasing does from 0.1 to $1.0 \mathrm{~Gy}$. However, the rates of developmental inhabitation were different among three behavioral events. Egg hatch was almost completely inhibited by $0.5 \mathrm{~Gy}$ and higher doses. Fecundity and hatchability of eggs were greatly reduced when pupae were irradiated at 0.1 $\mathrm{KGy}$ and completely inhibited at $0.25 \mathrm{KGy}$ and higher doses. This suggests that irradiation at $0.5 \mathrm{KGy}$ is appropriate for the inhabitation of development and reproduction of $\mathbf{P}$. interpunctella.

El-Kholy and Abd-El-Aziz (2010) studied the effect of gamma irradiation on the biology of greater wax moth, Galleria mellonella. When irradiated full grown pupae with 100,150,300 and 400Gy. The four doses given to male parents in the $F_{1}$ generation decreased the average number of eggs per mated female, the percentage of egg hatch. Dose dependence of the reduction in the fecundity and the percentage of egg hatch among the female line pairings (female descendants of irradiated parental male pupae) were more significant than among the male line pairings (male descendants of irradiated parental male pupae).

Mohamed (2012) studied the effect of gamma irradiation on some biological aspects of G. mellonella indicates that the average number of eggs per mated female was significantly decreased by increasing the dose rate and its more significantly decreased among the pairing (Normal male $\mathrm{X}$ Treated female) than the pairing (Treated male X Normal female). The lowest average was 80.67 eggs at the dose rate 300 Gy (Normal male X Treated female) and 30.33 eggs at the dose rate 400 Gy (Normal male X Treated female).

From the previous results turned out to be the Lc50 of Origanum majorana was ranged from $0.625 \%$ to $1.250 \%$ (Fig.1), estimated as $1.0166 \%$ (table, 2) and the larval mortality was ranged from $44 \%$ to $59 \%$ (Fig.1, Table,1 and Table, 2.1.). Also, Lc50 of Cymbopogon proximus was ranged from $1.25 \%$ to $2.50 \%$ (Fig.2), estimated as $1.7824 \%$ (table, 2) and the larval mortality was ranged from $33 \%$ to $81 \%$ (Fig.2, Table, 2 and Table, 2.2.). So, we irradiated the full grown pupae of parental male of GWM with the dose rate $100 \mathrm{~Gy}$ 
The impact of each of the essential oils of marjoram and lemon grass in conjunction with .....

then treated the $F_{1}$ larvae $\left(4^{\text {th }}\right.$ instar) with Lc50 of the plant essential oils Origanum majorana and Cymbopogon proximus.

Table (4): The effect of Gamma irradiation on fecundity and fertility of the Greater wax moth, galleria mellonella

\begin{tabular}{|c|c|c|c|}
\hline \multirow{2}{*}{$\begin{array}{l}\text { Dose } \\
\text { (Gy) }\end{array}$} & Pairings & \multirow{2}{*}{$\begin{array}{c}\text { Av. No. of } \\
\text { eggs / } q \\
\pm \text { SE }\end{array}$} & \multirow{2}{*}{$\begin{array}{c}\text { Hatch } \\
\% \\
\pm \text { SE } \\
\end{array}$} \\
\hline & $\widehat{0}$ & & \\
\hline Control (0) & $\mathrm{N} \quad \mathrm{X}$ & $1912.2 \pm 218.913 \mathbf{a}$ & $92.74 \pm 0.424 \mathbf{a}$ \\
\hline \multirow{3}{*}{100} & $\mathrm{~T} \underset{\mathrm{T} / \mathrm{C} \%{ }^{1}}{\mathrm{X}} \mathrm{N}$ & $\begin{array}{r}1387.4 \pm 195.070 \quad \mathbf{b} \\
\mathbf{7 2 . 5 6}\end{array}$ & $\begin{array}{r}63.92 \pm 0.519 \text { b } \\
\mathbf{6 8 . 9 2}\end{array}$ \\
\hline & $\begin{array}{ll}\mathrm{N} \underset{\text { T/C } \%}{\mathrm{X}} & \mathrm{T} \\
\end{array}$ & $\begin{array}{r}1254.4 \pm 195.070 \quad \mathbf{c} \\
\mathbf{6 5 . 6 0}\end{array}$ & $\begin{array}{r}33.86 \pm 0.940 \quad \text { d } \\
\mathbf{3 6 . 5 1}\end{array}$ \\
\hline & $\mathrm{T} \underset{\mathrm{T} / \mathrm{C} \%}{\mathrm{X} \%} \mathrm{~T}$ & $\begin{array}{r}0712.0 \pm 215.431 \\
\mathbf{3 7 . 2 3}\end{array}$ & $\begin{array}{r}10.86 \pm 0.475 \text { ef } \\
\mathbf{1 1 . 7 1}\end{array}$ \\
\hline \multirow{3}{*}{150} & $\mathrm{~T} \underset{\text { T/C } \%}{\mathrm{X}} \mathrm{N}$ & $\begin{array}{c}1186.0 \pm 182.868 \text { cd } \\
\mathbf{6 2 . 0 2}\end{array}$ & $\begin{array}{r}42.12 \pm 0.916 \text { c } \\
\mathbf{4 5 . 4 2}\end{array}$ \\
\hline & $\begin{array}{l}\mathrm{N} \underset{\text { T/C \% }}{\mathrm{X}} \\
\end{array}$ & $\begin{array}{rr}1033.6 \pm 143.667 & \mathrm{e} \\
\mathbf{5 4 . 0 5} & \end{array}$ & $\begin{array}{r}15.50 \pm 0.737 \quad \mathrm{e} \\
\mathbf{1 6 . 7 1}\end{array}$ \\
\hline & $\begin{array}{cc}\mathrm{T} & \mathrm{X} \\
\mathrm{T} / \mathrm{C} \% & \mathrm{~T} \\
\end{array}$ & $\begin{array}{rr}0680.0 \pm 183.715 & \text { fg } \\
\mathbf{3 5 . 5 6} & \\
\end{array}$ & $\begin{array}{r}05.10 \pm 0.303 \mathbf{f} \\
\mathbf{5 . 5 0}\end{array}$ \\
\hline \multirow{3}{*}{200} & $\begin{array}{l}\mathrm{T} \underset{\mathbf{T} / \mathbf{C} \%}{\mathrm{X}} \mathrm{N} \\
\end{array}$ & $\begin{array}{rr}0668.2 \pm 122.814 & \mathrm{~g} \\
\mathbf{3 4 . 9 4} & \\
\end{array}$ & $\begin{array}{r}19.76 \pm 1.237 \\
\mathbf{2 2 . 1 4}\end{array}$ \\
\hline & $\begin{array}{l}\mathrm{N} \\
\mathrm{T} / \mathrm{C} \%\end{array}$ & $\begin{array}{rr}0308.0 \pm 031.220 & \mathbf{h} \\
\mathbf{1 6 . 1 1} & \\
\end{array}$ & $\begin{array}{rr}03.12 \pm 0.629 & \mathrm{~g} \\
\mathbf{3 . 3 6} & \\
\end{array}$ \\
\hline & $\begin{array}{ll}\mathrm{T} \underset{\mathrm{T} / \mathrm{C} \%}{\mathrm{X}} & \mathrm{T} \\
& \end{array}$ & $\begin{array}{rr}0000.0 \pm 000.000 & \mathbf{k} \\
\mathbf{0 . 0 0} & \end{array}$ & $\begin{array}{rr}00.00 \pm 0.000 & \text { h } \\
\mathbf{0 . 0 0} & \end{array}$ \\
\hline \multirow{3}{*}{250} & $\begin{array}{l}\mathrm{T} \underset{\text { T/C \% }}{\mathrm{X}} \\
\mathrm{N}\end{array}$ & $\begin{array}{rr}0628.2 \pm 149.099 & \mathbf{g} \\
\mathbf{3 2 . 8 5} & \\
\end{array}$ & $\begin{array}{r}04.02 \pm 0.860 \\
\mathbf{4 . 3 3}\end{array}$ \\
\hline & $\begin{array}{l}\mathrm{N} \underset{\text { T/C \% }}{\mathrm{X}} \\
\end{array}$ & $\begin{array}{rr}0253.2 \pm 043.441 & \mathbf{i} \\
\mathbf{1 3 . 2 4} & \\
\end{array}$ & $\begin{array}{rr}00.98 \pm 0.171 & \mathbf{h} \\
\mathbf{1 . 0 6} & \end{array}$ \\
\hline & $\mathrm{T} \underset{\mathrm{T} / \mathrm{C} \%}{\mathrm{X} \%} \mathrm{~T}$ & $\begin{array}{rr}0000.0 \pm 000.000 & \mathbf{k} \\
\mathbf{0 . 0 0} & \end{array}$ & $\begin{array}{r}00.00 \pm 0.000 \\
\mathbf{0 . 0 0}\end{array}$ \\
\hline \multirow{3}{*}{300} & $\mathrm{~T} \underset{\text { T/C \% }}{\mathrm{X}} \mathrm{N}$ & $\begin{array}{rr}0626.8 \pm 121.777 & \mathbf{g} \\
\mathbf{3 2 . 7 8} & \end{array}$ & $\begin{array}{r}00.00 \pm 0.003 \\
\mathbf{0 . 0 0}\end{array}$ \\
\hline & $\mathrm{N} \underset{\text { T/C \% }}{\mathrm{X}} \mathrm{T}$ & $\begin{array}{r}0180.0 \pm 043.769 \\
\mathbf{9 . 4 1}\end{array}$ & $\begin{array}{rr}00.00 \pm 0.000 & \text { h } \\
\mathbf{0 . 0 0} & \end{array}$ \\
\hline & $\mathrm{T} \underset{\text { T/C \% }}{\mathrm{X}} \mathrm{T}^{\mathrm{T}}$ & $\begin{array}{rr}0000.0 \pm 000.000 & \mathbf{k} \\
\mathbf{0 . 0 0} & \end{array}$ & $\begin{array}{rr}00.00 \pm 0.000 & \mathbf{h} \\
\mathbf{0 . 0 0} & \end{array}$ \\
\hline \multicolumn{2}{|c|}{$\begin{array}{ll}\text { P } & 0.05 \\
\end{array}$} & $0.0479 *$ & $0.0000 * * *$ \\
\hline \multicolumn{2}{|c|}{ LSD 0.05} & 419.4656 & 1.526789 \\
\hline
\end{tabular}

$1-\mathrm{T} / \mathrm{C} \%=$ Treatment $/$ Control X100

2- Means followed by the same letter in each column are not significantly different at $(\mathrm{p}>0.05)$

Table, 5 and figure, 3 demonstrates the combined effect of 100 Gy of Gamma irradiations and Lc50 of the two volatile oils on some biological aspects of the Greater wax moth, Galleria mellonella (the percentage larval mortality, the percentage pupation, the percentage emergence, sex ratio and the percentage survival).

The percentage larval mortality was significantly increased to $435.71 \%$ from the untreated control when irradiated with $100 \mathrm{~Gy}$ of gamma radiation only, and then significantly increased to $700.00 \%$ from the untreated control when treated with the Lc50 of Origanium Majorana only. While, it was significantly increased to $814.29 \%$ from the untreated control when irradiated by 100 Gy combined with the Lc50 of Origanium Majorana.

The Lc50 of volatile oil, Cymbopogon proximus significantly increase the percentage larval mortality to $328.57 \%$ from the untreated control, as well, it significantly increased to $471.43 \%$ from the untreated control when combined with $100 \mathrm{~Gy}$ of gamma radiation. It is noted that the combined influence of both the essential oil and the gamma radiation higher than the essential oil alone. 
Table (5): The combined effect of 100 Gy of Gamma irradiation and Lc50 of Origanium majorana and Cymbopogon proximus volatile oils on some biological aspects of the Greater wax moth, Galleria mellonella

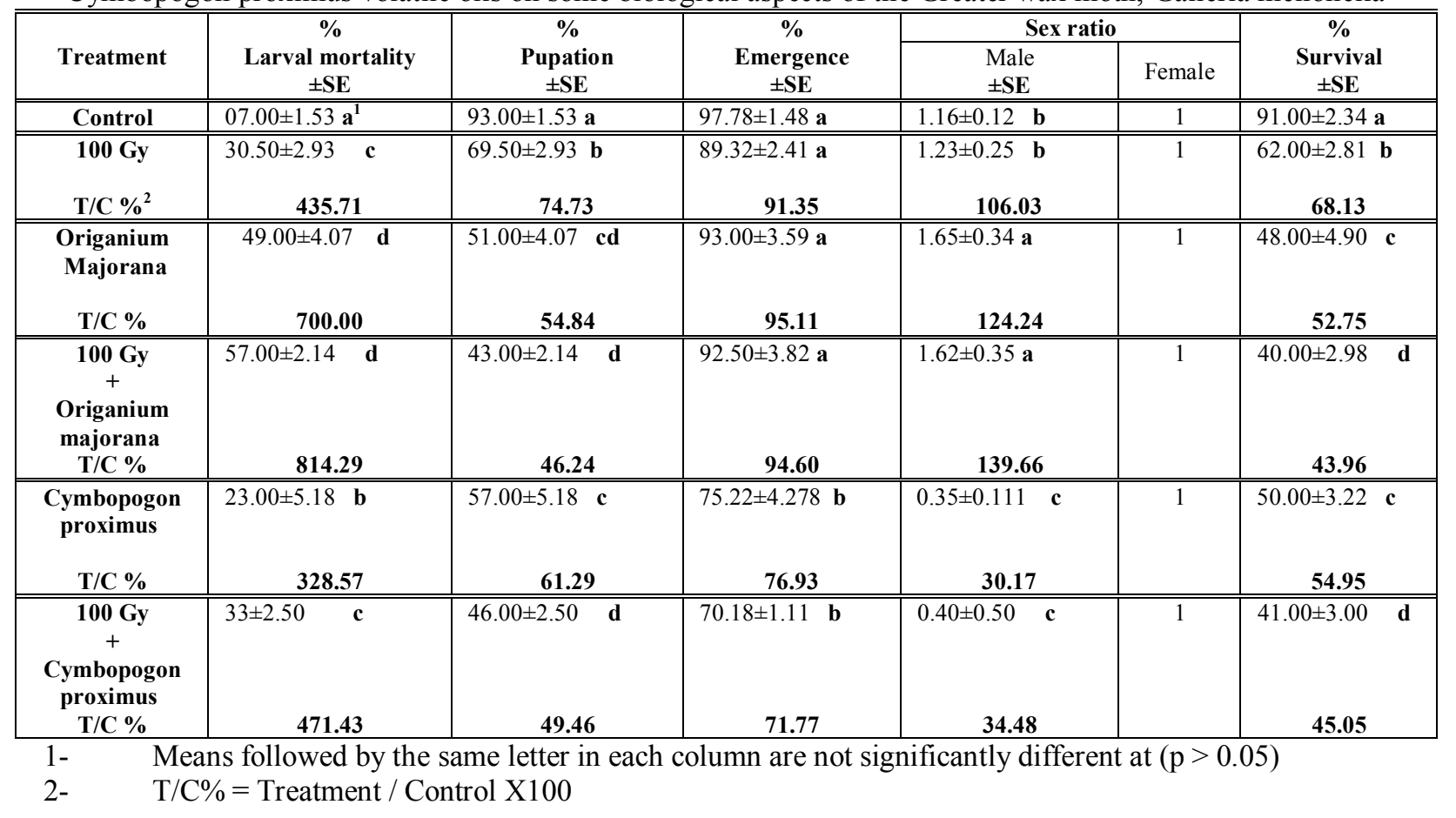

The percentage pupation significantly reduced at all treatments than the untreated control treatment. It was significantly reduced to $74.73 \%, 54.84 \%$ and $61.29 \%$ from the untreated control treatment among $100 \mathrm{~Gy}$ treatments and the Lc50 of both volatile oils Origanium Majorana and Cymbopogon proximus respectively. While, it was significantly more reduce to $46.24 \%$ and $49.46 \%$ from the untreated control at the both combined (100 Gy+ Origanium Majorana) and (100 Gy + Cymbopogon proximus) treatments respectively. The sex ratio significantly reduced at all treatments than the untreated control treatment, except, the dose rate $100 \mathrm{~Gy}$ not significantly reduced than the untreated control treatment.

Also, the percentage survival significantly reduced at all treatments than the untreated control treatment. It was significantly reduced to $68.13 \%, 52.75 \%$ and $54.95 \%$ from the control treatment at $100 \mathrm{~Gy}$ treatments and the Lc50 of both volatile oils Origanium Majorana and Cymbopogon proximus respectively. While, it was significantly more reduce to $43.96 \%$ and $45.05 \%$ from the untreated control at the both combined (100 Gy+ Origanium Majorana) and (100 Gy + Cymbopogon proximus) treatments respectively.

The adverse effect of irradiation on the reproductive potential was found to be greater for females than for males, and these results are in agreement with Knipling (1970), Carpenter et al. (1986). These findings are agree with those obtained by Ali (1992) who studied the effect of gamma irradiation (100Gy) in combination with the (Lc50) of botanical oils tested (canola, sunflower and sesame) against the 3rd larval instar of A. ipsilon resulted from (irradiated males crossed with irradiated females), or from non-irradiation males crossed with irradiated females or from irradiated males crossed with non-irradiated females on some biological aspects was studied. As shown from the results obtained the combined effect of gamma irradiation (100Gy) and the (Lc50) of botanical oils tested markedly affected the different biological aspects of A. ipsilon. Increased the larval and pupal mortality; prolonged the larval and pupal duration; reduced the percentage of adult emergence. Moreover, the combined effect of gamma irradiation and oils treatment against the 3rd instar larvae of A. ipsilon drastically decreased the number of eggs/ $/$ (fecundity), increased the sterility percentage and decreased the egghatchability percent. The present study indicated that the combined effect of gamma irradiation and botanical oils induced more remarkable effects as compared to gamma irradiation or botanical oils each of them alone.

Mohamed (2004) mentioned that the females were more radiosensitive than males as determined by the reduction in fecundity and egg viability. The effect of the plant extract Barnoof on the reproductive behavior among the $\mathrm{F}_{1}$ generation descended from $\mathrm{P}_{1}\left(\mathrm{~N}_{\hat{\gamma}} \mathrm{x} N\right.$ N $)$. The adverse effect of the plant extract Barnoof on the reproductive potential was found to be greater for females than for males when the $F_{1}$ progeny were treated with acetone dissolved extract at all treatment levels, but this was not true among $\mathrm{F}_{1}$ progeny treated with petroleumether-dissolved extract. The sterility effect was greater for females than for males at the treatment levels of $1.5 \%$ and 3\% extract dissolved in petroleum ether. The effect on the reproduction of A. ipsilon following the application of the plant extract Barnoof to $F_{1}$ progeny descended from parental male pupae irradiated with a 100 
Gy dose. The data also indicate that the adverse effect of the combination of irradiation and plant extract on the reproductive potential was found to be reduced for males. El-Nagar et al. (2004), Mohamed (2004) and ElShall and Mohamed (2005) studied The effect of the application of the plant extract Barnoof on A. ipsilon $F_{1}$ progeny descended from parental male pupae irradiated with the 150 Gy dose. The data show a slight effect when acetone-dissolved extract was used, but the adverse effects on the reproductive potential found when the combination of irradiation and plant extract dissolved in petroleum ether was used was greater for females than for males. This result is also in agreement with the previous authors. Originally, the radiosensitivity and inherited sterility among $F_{1}$ progeny of the two substerilizing doses of radiation (100 or $150 \mathrm{~Gy}$ ) in male A. ipsilon was assessed with regard to the combination of both a 100 or $150 \mathrm{~Gy}$ dose of gamma radiation and the plant extract Barnoof. The male moth descendants of irradiated parental male pupae were found to be better candidates for producing more inherited sterility among $\mathrm{F}_{1}$ progeny.

Also, are agree with those obtained by EL-Shall and Mohamed (2005) using barnoof plant extract combined with gamma irradiation against A. ipsilon. Moreover, the present study indicated that treatment of both partners of mating pair induced more remarkable effects than did treatment of either sex separately. ElShall and Mohamed (2005) stated that the effect of plant extract (Barnoof) only was significantly deference at the two tested concentration 1.5 and $3 \%$ to the two solvents (Acetone and Petroleum ether) when compared with the untreated control. The combined effect of gamma radiation (fullgrown pupae) and plant extract $\left(\mathrm{F}_{1}\right.$ larvae) were significantly decreased the growth rate of the larvae when compared with the untreated larvae which enhanced the consumption index of the larvae. El-Sinary (2006) reported that the combined effect of pumpkin leaves and seed oil and gamma-irradiation (20 and $40 \mathrm{~Gy}$ ) drastically decreased emergence percentage, fecundity and fertility. Mohamed (2006) studied the effects of two gamma substerilizing doses (100 and 150 Gray) applied to full grown pupae of Agrotis ipsilon (Hufn.) and/or the plant extract (with two different solvents of Conyza dioscorides (Barnoof) applied to the resulting $4^{\text {th }}$ instar larvae of $F_{1}$ generation. He revealed that the average number of eggs, $\%$ egg hatch and $\%$ mating. Throughout $\mathrm{F}_{1}$ generation, the plant extract alone significantly decreases the fecundity using the two extract solvents, acetone and petroleum ether while the \% egg viability, mating ability, and mating frequency among the two extract solvents ( acetone and petroleum ether ) while the \% egg viability was not affected in case of acetone extract only. Gamma irradiation when combined with the extract in most treatments significantly lowered the fecundity, \% egg hatch and mating ability at all treatments (gamma doses and extract concentrations).

Amin et al (2010) mintioned that Spiny bollworm, Earias insulana Boisd. adult males were irradiated with substerilizing doses of 50,80,100 and 150 Gray (Gy) of gamma radiation. The number of surviving larvae was dose dependant and larval/pupal mortality increased as the dose applied to $\mathrm{P}_{1}$ males was increased. The larval mortality among $F_{3}$ was reduced compared with that of the $F_{1}$ and $F_{2}$. The average developmental time from egg hatch to adult emergence at the four tested doses was slightly affected among the progeny descendant of irradiated $\mathrm{P}_{1}$ males through the three successive generations. The percentage of adult emergence was evidently reduced among $F_{1}$ and $F_{2}$ progeny resulting from parental males exposed to the three higher irradiation doses $(80,100$ and $150 \mathrm{~Gy})$.The sex ratio was slightly altered in favour of males among the majority of all treatments. Mohamed (2012) mentioned that the combined effect of gamma irradiation and plant extract (Neem) on som biological aspects of G. mellonella irradiated parental males and females with 100,200,300 and $400 \mathrm{~Gy}$. The percentage larval mortality and pupal mortality were increase by increasing the dose of gamma radiation combined with the concentration of the plant extract (Neem). The percentage of larval mortality increased to $100 \%$ at the dose rate $400 \mathrm{~Gy}$ (Normal male X Treated female) and at the combined treatment 400 Gy +15 ppm (Normal male X Treated female). The percentage larval mortality increased to $92.25 \%$ at the combined treatment $400 \mathrm{~Gy}+15 \mathrm{ppm}$ (Normal male X Treated female). The percentage of pupation, Emergence and adult survival were more decrease than the control treatment by increasing the dose and the concentration at all treatments. The lowest decrease in the percentage pupation was Zero at the dose rate 400 Gy (Normal male X Treated female) and at the combined treatment $400 \mathrm{~Gy}+15 \mathrm{ppm}$ (Normal male X Treated female). In addition, the lowest decrease in the percentage emergence was $7.75 \%$ at the combined treatment 400 Gy +15 ppm (Normal male X Treated female). The percentages of adult survival so on. Mohamed (2013) investigated the effects of two substerilizing doses of gamma radiation, 100 and 150 Gray (Gy), and/or the plant extract Conyza dioscorides (Barnoof) in two solvents on certain biological aspects of the Black cutworm, Agrotis ipsilon (Hufnagel). Data revealed that the treatment combination of gamma radiation with the plant extract significantly increased reproduction compared with the control at all treatment levels (doses and concentrations). The reproductive behavior of full-grown male A. ipsilon pupae after treatment was observed among the $\mathrm{P}_{1}$ and $\mathrm{F}_{1}$ generations. 


\section{Conclusion}

It could be concluded that inherited sterility is usually not a "stand alone" technology but is also a complementary component of an area-wide and sustainable long-term strategy in Integrated Pest Management (IPM) (El-Shall and Mohamed, 2005; Mohamed, 2013).

Employing the synthetic insecticides remains undesirable effects such as mammalian toxicity, food chain disruption and increases resistance in insect population (Regnault-Roger, 1997). Natural compounds from plant origins could be efficient alternatives for conventional fumigants because of their low toxicity to mammals, fast degradability properties and regional availability (Rajendran \& Sriranjini, 2008; Hosseinpour et al., 2009; Abbasipour et al., 2009 and Mahmoudvand et al., 2011).

Plant extracts are currently studied more and more because of their role in plant protection as well as in urban entomology (Din et al., 2001). Plant extracts are safer for non target organisms including man, therefore, plant based formulations would be more feasible from environmental perspective than synthetic larvicides (Bhat et al., 2009). Aromatic plants and their essential oils are very important sources of many compounds that are used in different respects (Amer and Mehlhorn, 2006).

Compatible control methods, such as plant extracts, that possess a source for naturally occurring substances which act as feeding and insect growth deterrents, may be synergistic when integrated with the SIT. The present data indicate that the treatment combination of irradiation and plant essential oils resulted in less fecundity, fertility and more larval mortality compared with the use of irradiation alone (Mohamed, 2004; Mohamed, 2013). Furthermore, fertility is a fundamental parameter in the assessment of any control measure. The treatment combination of plant essential oils and gamma radiation on GWM decreased the fertility of moths more than the decrease in fertility that resulted from the irradiation treatments alone. Further critical evaluations need to be conducted, both in the laboratory and in the field, on the effect of gamma radiation and/or plant essential oils for the assessment of the use of plant essential oils to suppress the pest population before introducing the SIT (Mohamed, 2013).

Finally, in this work, we attempted to control GWM with certain volatile plant oils which seem to be safer and less contaminant to bees and humans. Also, these materials are cheap, available to beekeepers, and could be used to control other hive infestations e.g. Varroa and acarine mites .etc. Also, we conclude that the combined treated with gamma irradiation and plant volatile oil were establish results more significantly affected than both gamma radiation and plant volatile oil each of them alone.

\section{References}

[1]. Abbasipour, H., Mahmoudvand, M., Deylami, A. \& Hosseinpour, M. H. 2009. Fumigant toxicity of essential oils of Rosemarinus officinalis L. and Eucalyptus camodulensis Deh. against some stored products pests, Proceeding of the 6th Asia-Pasific Congress of Entomology, Entomology in Health, Agriculture and Environment, Beijing, China.

[2]. Abd El-Hamid 2004. Effect of gamma irradiation on certain biological and physiological aspects of black cut worm Agrotis ipsilon (Hufn). M.Sc Thesis. Fac. Agric.Cairo Univ.

[3]. Abou El-Ghar, G. E. S., Khalil, M. E. and Eid, T.M. 1996. Some biochemical effects of plant extracts in the black cutworm, Agrotis ipsilon (Hufn.) (Lep., Noctuidae).J.Appl.Ent.,482-477 (8)120

[4]. Ahn, Y.J., Kwon, M., Park, H.M. and Han, C.G. 1997. Potent insecticidal activity of Ginkgo biloba-derived trilactone terpenes against Nilaparvata lugens. In phytochemical pest control Agents; Hedin, P. Hollingworth, R., Miyamoto, J., Masler, E., Thompson, D., Eds.; Acs Symposium series 658; American Chemical society: Washington, DC., pp. 90 - 105.

[5]. Ali, A. G. A. 1992. Biological and Physiological Studies on the Effect Of Some Botanical Oils and Gamma Irradiation on The Greasy Cut Worm Agrotis Ipsilon (Huf). A thesis Master of Science In Entomology Al-Azhar University Faculty of Science (Girls branch) Zoology Department

[6]. Amin, A.R.H., Sallam, H.A. and Mohamed, H.F. 2010. Inherited Sterility Induced in Progeny of Gamma Irradiated Males Spiny Bollworm, Earias Insulana Boisd. П. Effect on Larval and Pupal Mortality, Development and Sex Ratio. 2nd International Conference on Radiation Sciences and Applications, 28/3 - 1/4/2010 Marsa Alam, Egypt, 174-181.

[7]. Amer A, Mehlhorn H. 2006. Larvicidal effects of various essential oils against Aedes, Anopheles, and Culex larvae (Diptera, Culicidae). Parasitol Res ; 99: 466-472.

[8]. Aranson, J.T., Philogne, B.J.R. and Morand, P. 1989. Insecticides of plant origin; ACS symposium series 387; Amer. Chem. Soc., Washington, DC, pp.164-172.

[9]. Ayari1, B., Riahi, L., Landoulsi, A. 2013. Variability of phenolic contents in methanolic extracts of Origanum majorana L. organs and effect on antioxidant and antimicrobial activities International Journal of Agronomy and Plant Production. Vol., 4 (11), 28062815 .

[10]. Aye T. T., Jae-Kyoung Shim, Dae-Myung Ha, Yong-Jung Kwon, Joong-Ho Kwon and Kyeong-Yeoll Lee 2008. Effects of gamma irradiation on the development and reproduction of Plodia interpunctella (Hubner) (Lepidoptera:Pyralidae).J. Stored Products Research, 44 (2008) 77-81.

[11]. Bakkali, F., Averbeck, S., Averbeck, D., Idaomar, M.M. 2008. Biological effects of essential oils- a

[12]. review. Food Chem. Toxicol. 46, 446-475.

[13]. Bakr, R.F.A., Abdel Fattah, H.M., Salim, N.M. and Atiya, N.H. 2010. Insecticidal activity of Four Volatile Oils on Two Museum Insects Pests. Egypt. Acad. J. biolog. Sci., 2 (2): 57- 66.F. Toxicology \&Pest control.

[14]. Balandrin, M. F., Klocke J.A.,Wurtele E.S. and Bollinger W.H. 1985. Natural plant chemicals: sources of industrial and medicinal materials. Sci., 228: 1154-1160.

[15]. Baratta, M.T., Dorman, H.J.D., Deans, S.G., Biondi, D.M., Ruberto, G., 1998. Chemical composition, antimicrobial and oxidative activity of laurel, sage, rosemary, oregano and coriander essential oils. J. Essent. Oil Res. 10, 618-627. 
[16]. Barwick, R.S. et al. 2000. Surveillance for waterbornedisease outbreaks - United States, 1997-1998. MMWR CDC Surveill Summ., v. 49 , p. $1-21$.

[17]. Baxter, R. C. and Blair H. A. 1969. Recovery and over recovery from acute radiation injury as a function of age in Drosophila. Rad. Res., 39: 345-360.

[18]. Bekele, A.J., Obeng-Ofori, D., Hassanali, A.1996. Evaluation of Ocimum suave (Willd) as a source of repellent, toxicants and protectants in storage against three stored product insect pests. International Journal of Pest Management. 42(2): 139-142.

[19]. Bhat, S.K., Kempraj, K. 2009. Biocidal potential of clove oil against Aedes albopictus - A comparative study. Afr J Biotechnol, 8: 6933-6937.Bouda, H., Tapondjo, A., Fotem, D.A., Gumedzoe, M.Y.D. 2001. Effect of essential oils from leaves of Ageratum conyzoides, Lantana Camara and Chromolaena odorata on the mortality of Sitophilus zeamais (Coleoptera, Curculionidae). Journal of Stored Products Research. 37(2): 103-109

[20]. Brugnera, D.F., Mattos de Oliveira, M.M., Piccoli, R.H. 2011. Essential Oils of Cymbopogon SP. in the Control of Foodborne Pathogenic Bacterla Alim. Nutr., Araraquara v. 22, n. 3, p. 339-343, jul./set.

[21]. Burt, S., 2004. Essential oils: their antibacterial properties and potential applications in foods-a review. Int. J. Food Microbiol. 94 , 223-253.

[22]. Busattaa, C., Vidala, R.S., Popiolskia, A.S., Mossia, A.J., Darivab, M.R.A., Rodriguesc, C., Corazzaa, F.C., Corazzaa, M.L. , Vladimir Oliveiraa, J., Cansiana, R.L. 2008. Application of Origanum majorana L. essential oil as an antimicrobial agent in sausage. Food Microbiology 25, 207-211.

[23]. Calderone, N. 2000. IPM- wax moths, mice, wasps and robber bees. (Bee Culture Magazine. Jan. Issue).

[24]. Carpenter, J.E., Young, J.R., Sparks, A.N., 1986. Full army worm, Spodoptera frugiperda Lepidoptera-Noctuidae: comparison of inherited deleterious effects in progeny from irradiated males and females. J. Econ. Entomol. 79, p46.

[25]. Castro, L. O., Ramos, R. L. D. 2003. Principais gramíneas produtoras de óleos essenciais: Cymbopogon citrates (DC) Stapf., capim-cidró, Cymbopogon martinii (Rox.) J.F. Watson, palma-rosa, Cymbopogon nardus (L.) Rendle, citronela, Elyonurus candidus (Trin.) Hack., capim-limão, Vetiveria zizanioides (L.) Nash, vetiver. Porto Alegre: FEPAGRO. 28p.

[26]. Charriere, Jean-Daniel and Imdorf, A.1997. Protection of honey combs form moth damage. (Swiss Bee Research Centre, Fedral Dairy Research Station, Liebfeld, CH-3003 Bern. Communication No.24).

[27]. Chaubey, M.K. 2007. Insecticidal activity of Trachyspermum ammi (Umbelliferae), Anethum graveolens (Umbelliferae) and Nigella sativa (Ranunculaceae) against stored-product beetle Tribolium castaneum Herbst (Coleoptera: Tenebrionidae). African Journal of Agriculture Research. 2(11): 596-600.

[28]. Daferera, D.J., Ziogas, B.N., Polissiou, M.G., 2000. GC-MS analysis of essential oils from some Greek aromatic plants and their fungitoxicity on Penicillium digitatum. J. Agric. Food Chem. 48, 2576-2581.

[29]. Deans, S.G., Svoboda, K.P., 1990. The antimicrobial proprieties of marjoram (Origanum majorana L.) volatile oil. Flavour Fragrance J. 5, 187-190.

[30]. Din S, Akram W, Khan HAA, Hussain A, Hafeez F.2001. Citrus Waste- Derived Essential Oils: Alternative Larvicides for Dengue Fever Mosquito, Aedes albopictus (Skuse) (Culicidae: Diptera). Pakistan J Zool. 43: 367-372.

[31]. El-Assiuty, E.M., Bekheet, F.M., Zeinab M., Fahmy, Ismael, A.M. and El-Alfy, T.S.M. 2006a. Potentiality of some Isolated Compounds from Halfa Barr (Cymbopogon proximus Stapf.) against the Toxigenic Fungi Fusarium verticillioides and Aspergillus flavus Egypt. J. Phytopathol., Vol. 34, No. 2, pp. 75-84 .

[32]. El-Assiuty, E.M. Fahmy, Zeinab M., Bekheet, Fawziya M., Ismael, A.M. and Hob-Allah. 2006b. Effect of some medicinal and indigenous plant extracts on some plant pathogens and mycotoxin production in vitro. Egypt. J.Agric. Res., 84 (5): 1345-1358.

[33]. El-Kady, E. A., Salem, Y. S. and Hekal, A. M. 1983. Effect of gamma irradiation on pupae of the greasy cutworm, Agrotis ipsilon (Hufn.) (Lepidoptera: Noctuidae). Mededelingen-vande-Faculteit-Landbouwwetenschappen,-Rijksuniversiteit-Gent. 48(2): 385392.

[34]. El-Kholy, E.M.S and Abd-EL-Aziz ,L.M. 2010. Effect of gamma irradiation on the biology and ultrastructure of haemocytes of gonads moth Galleria mellonella (L.) Lepidoptera, Pyralidae. Isotop \& Rad. Research, 68: 1671- 1676.

[35]. El-Naggar, S. E. M., Ibrahim, S. M., El-Shall, S. S. A. 1999. Mating Competitiveness of Agrotis ipsilon (Hufn.).Arab J. of Nuc. Sci. and Applications, v. 33(3) p. 22 5-2 31.

[36]. El-Naggar, S.E.M., Ibrahim, S.M., Mohamed, H.F., 2004. Combined and separate effects of gamma irradiation and barnoof plant extract on the dietary profile of the black cutworm, Agrotis ipsilon (Hufn.) I-Treatment of the eight days-old larvae. Seventh Arab Conference on the Peaceful Applications of Atomic Energy, Sanna, a, Yemen; 4-8 Dec.

[37]. El-Naggar, S. , Megahed, M. M. , Sallam, H. A., Ibrahim, S.M. 1984. Inherited sterility among Agrotis ipsilon laboratory population, exposed to gamma irradiation. Insect Sci. and Application, 5(6): 501-503.

[38]. El-Shall, S.S.A., El-Naggar, S.E.M., Ibrahim, S.M. (1997) Radiation induced inherited sterility and mating competitiveness in the maize worm, Mythimne loreyi (Dup.). Bull. Ent. Soc. Egypt., Econ. Ser., 24, 150.

[39]. El-Shall, S.S.A., Mohamed, H.F., 2005. The combined effect of gamma irradiation and plant extract (Barnoof) on the nutritional profile of the Black cutworm, Agrotis ipsilon (Hufn.) (Lepidoptera: Noctuidae), II —-the effect on the $\mathrm{F}_{1}$ progeny during the 5 th and 6th instars larvae. Arab J. Nucl. Sci. Appl. 38 (2),289.

[40]. El-Shazly, A.M. and Hussein, K.T. 2004. Chemical analysis and biological activities of the essential oil of Teucrium leucocladum Boiss. (Lamiaceae). Biochem. Syst. and Ecology, 32(7): 665-674.

[41]. El-Sinary, N. H. 2006. Evaluation of the insecticidal effect of pumpkin Cucurbita pepo against potato tuber moth Phthorimaea operculella (Zeller) combined with gamma irradiation. American Eurasian Journal of Scientific Research 1 (1): 18-22.

[42]. Emara, S., Bakr F. R., EL-Bermawy S., Abulyazid I. and Abdelwahab H. 2002. Biological effects of four botanical extracts on the different developmental stages of cotton leaf worm. Spodoptera littoralis. 2nd Inter. Conf., Plant Protection Research Institute, Cairo. vol. 1, 904-916.

[43]. Erturk, O. 2006. Antifeedant and toxicity effects of some plant extracts on Thaumetopoae solitaria (Frey.) (Lep., Thaumetopoeidae). Turk. J. Biol. 30(2006) 51-57.

[44]. Ezzeddine, N.B., Abdelkefi, M.M., Ben-Aissa, R., Chaabouni, M.M., 2001. Antibacterial screening of Origanum majorana L. oil from Tunisia. J. Essent. Oil Res. 13, 295-297.

[45]. Farooqi, A. A. and Sreeramu, B.S. 2004. Sreeramu: Cultivation of medicinal and aromatic crops.Universities Press, India. pp. 465470 .

[46]. Fraser, H.W. 1997. The effect of different conspecific male sex pheromone component ratios on the behaviour of the female greater wax moth, Galleria mellonella L. (Lepidoptera: Pyralidae). (M.Sc.Thesis,Univ.Gueiph,Canada).

[47]. Grad, A. A. 2010. "Biological properties of essential oils - an update" Magistra der Pharmazie (Mag.pharm.) Univ. Wien. 61 pp.

[48]. Hassanali, A., Lwande, W., Ole-Sitayo, N., Moreka, L., Nokoe, S., Chapya, A. 1990. Weevil repellent constituents of Ocimum suave leaves and Eugenia caryophylla cloves used as grain protectant in parts of East Africa. Disc. Inno. 2: 91-95. 
[49]. Hofmeyr, H., Hofmeyr, M., Bloem, S.and Carpenter, J. 2004. Control of false codling moth using sterile insect release: laboratory trials., SA Fruit J., 3(4): 55-59.

[50]. Holley, R.A., Patel, D., 2005. Improvement in shelf-life and safety of perishable foods by plant essential oils and smoke antimicrobials. Food Microbiol. 22, 273-292.

[51]. Hosseinpour, M. H., Askarianzadeh, A., Moharramipour, S. \& Jalali Sendi, J. 2009. Fumigant toxicity of essential oils of Artemisia unnua L. (Asteraceae) against two stored products coleopteran insect pests, Proceeding of the 6th Asia-Pasific Congress of Entomology Entomology in Health, Agriculture and Environment, Beijing, China.

[52]. Ibrahim, 1981. Studies on the effect of gamma irradiation of the black cutworm Agrotis ipsilon. Bull. Ent. Soc. Egypt., (114p.)

[53]. Ibrahim, S.M., El-Naggar, S.E.M. and El-Shall, S.S.A. (1999): Inheritance of radiation induced partial sterility among $F_{1}$ larval and adult males of the cutworm, Agrotis ipsilon (Hufn), (histological studies). Arab J. of Nucl. Sci. and Appl., 32 : 301-309

[54]. Ibrahim, M.A., Kainulainen, P., Aflatuni, A., Tiilikkala, K., Holopainen, J.K. 2001. Insecticidal, repellent, antimicrobial activity and Phytotoxicity of essential oils: with special reference to limonene and its suitability for control of insect pests. Agr. Food Sci. Finland , 10, 243-259.

[55]. Jain, K. L., Jain, H. K., Shekhawat, K. S. 2005. Growth inhibiting effect of some non-edible oils on Achaea janata (Linn). J. Appl. Zool. Res., 16(2): 192-194

[56]. Kirtikar, K. R. and Basu, B. D.1985. Indian medicinal plants. (Eds.: E. Blatter, J.F.Caius and S.K.Mhaskar). Bishen Singh and Mahendra Pal Sing, Dehradun. Vol. 3, pp. 250.

[57]. Khalaf, A.A., Hussein, K.T. and Shoukry, K.K. 2009. Biocidal Activity of two botanical volatile oils against the larvae of Synthesiomyia nudiseta (Wulp) (Diptera: Muscidae). Egypt. Acad. J. biolog. Sci., 2 (1) : 89 - 101.

[58]. Khambay, B.P.S., Beddie, D.G. and Simmands, M.S.J. 2002. An insecticidal mixture of tetramethyl cyclohexenedione isomers from Kunzea ambigua and Kunzea baxterii. Phytochemistry. 59(1): 69-71.

[59]. Knipling, E. F.1955. Possibilities of insect control or eradication through the use of sexually sterile males. J. Econ. Ent., 48(3);459462 .

[60]. Ko, K., Juntarajumnong, W., Chandrapatya, A. 2009. Repellency, Fumigant and Contact Toxicities of Litsea cubeba (Lour.) Persoon against Sitophilous zeamais Motschulsky and Tribolium castaneum Herbst. Kasetsart Journal (Natural Science). 43(1):5663.

[61]. Koul, O., Walia,S. and Dhaliwal, G. S. 2008. Essential Oils as Green Pesticides: Potential and Constraints. Biopestic. Int. 4(1): 6384.

[62]. Kwon, M., Ahn, Y.J., Yoo, J.K and Choi, B.R. 1996. Potent insecticidal activity of extracts from Ginkgo biloba leaves against Nilaparvata lugens (Homoptera: Delphacidae). Appl. Entomol., Zool., 31L 162- 166.

[63]. La Chance, L.E., Bell, R. A. and Richared, R. D. 1973. Effect of Low Doses of Gamma Irradiation on Reproduction of Male Pink Bollworms and Their $\mathrm{F}_{1}$ Progeny. Environ. Entomol. 2,653.

[64]. Leeja, L. and Thoppil, J. E. 2007. Antimicrobial activity of methanol extract of Origanum majorana L. (Sweet marjoram). Journal of Environmental Biology 28(1) 145-146.

[65]. Lorenzi, H., Matos, F. J. A. 2002. Plantas medicinais no Brasil: nativas e exóticas cultivadas. Nova Odessa: Plantarum. 512p.

[66]. Mahmoudvand, M., Habib Abbasipour,H., Mohammad Hossein Hosseinpour, M.H., Fahimeh Rastegar, F. and Basij, M. 2011. Using Some Plant Essential Oils As Natural Fumigants Against Adults of Callosobruchus Maculatus (F.) (Coleoptera: Bruchidae). Mun. Ent. Zool. Vol. 6, No. 1,150-154.

[67]. Malarvannan, S. and Subashini, H.D. 2007. Effect of Dodonaea angustifolia crude extract on biochemical profile of Helicoverpa armigera (Hubner) (Noctuidae: Lepidoptera), Biochem. and Cellular Archives; 7 (1): 1-8.

[68]. Miguel, M.G. 2010. Antioxidant and Anti-Inflammatory Activities of Essential Oils:A Short Review. Molecules 2010, 15, $9252-$ 9287; doi: $10.3390 /$ molecules15129252.

[69]. Milan, V. G. 1970. Moth pests of honey bee combs. Glean. Bee Culture, 68:424-428.

[70]. Ming, L.C., Figueiredo, R.O., Machado, S.R., Andrade, R.M.C.1996. Yield of essential oil and citral content in different parts of lemongrass leaves (Cymbopogon citratus (DC.) Stapf) - Poaceae. Acta Hort., v. 426, p. 555-559.

[71]. Mishra, B.B., Tripathi, S.P. 2011. Repellent activity of plant derived essential oils against Sitophilous oryzae (Linnaeus) and Tribolium castenium (Herbst). Singapore Journal of Scientific Research. 1 (2):173-178.

[72]. Mishra, B.B., Tripathi, S.P., Tripathi, C.P.M. 2012. Repellent effect of leaves essential oils from Eucalyptus globulus (Mirtaceae) and Ocimum basilicum (Lamiaceae) against two major stored grain insect pests of Coleopterons Nature and Science, 10 (2);50-54.

[73]. Moawad, S. S. and Ebadah I. M. A. 2007. Impact of some natural plant oils on some biological aspects of potato tuber moth Phthorimaea operculella, (Zeller) (Lepidoptera: Gelechiidae) .Rese. J. Agric. and Biol. Sci., 3(2) 119-123.

[74]. Mohamed, H.F., 2004. Inherited sterility induced by gamma irradiation and/or Barnoof plant extract on reproductive potential and mating ability of the black cutworm, Agrotis ipsilon (Hufngel) (Lepidoptera: Noctuidae). Isot. Radiat. Res. 36 (4), 713.

[75]. Mohamed, H.F., 2006. Effects of gamma irradiation and leaves extract of barnoof plant on larval development of Agrotis ipsilon (Hufngel). Arab J. Nucl. Sci. Appl. 39 (2), 255.

[76]. Mohamed,H.F. 2012. The Biological Effects of Gamma Irradiation and / or Plant Extract (Neem) on the Greater Wax Moth, Galleria Mollenella. Eleventh Arab Conference on the Peaceful Uses of Atomic Energy, Khartoum, Sudan, 16-20 December 2012

[77]. Mohamed, H.F. 2013. Bioenergetics growth model for the effect of gamma irradiation and plant extract (Barnoof) on the progeny of Black cutworm, Agrotis ipsilon (Hufnagel) Applied Radiation and Isotopes 73, 101-108.

[78]. Mohamed, H.F., EL-Naggar, S.E.M., Mohamed, A.Z., 2004. The combined effect of gamma irradiation and plant extract barnoof on the nutritional profile to the black cutworm, Agrotis ipsilon, III. The effect on some haemolymph digestive enzyme activities. J. Egypt. Acad. Soc. Environ. Dev. (C-Mol. Biol.) 5 (2), 99.

[79]. Nerio, L.S., Olivero-Verbel, J., Stashenko, E. 2010. Bioresour Technol. 101, 372.

[80]. North, D. T. and Holt, G. G. 1968. Inherited Sterility in Progeny of Irradiated Male Cabbage Loopers. J.Econ. Entomol. 61,928.

[81]. Pavela, R. 2005. Insecticidal activity of some essential oils against larvae of Spodoptera littoralis. Fitoterapia-, 76(7/8): 691-696.

[82]. Popović, A., Šućur,j., Orčić , D. , Štrbac, P. 2013. Effects of Essential Oil Formulations on The Adult Insect Tribolium Castaneun (Herbst) (Col., Tenebrionidae) Journal of Central European Agriculture, 14(2), p.181-193.

[83]. Prowse, G.M., Galloway, T.S., Foggo, A. 2006. Insecticidal activity of garlic juice in two dipteran pests. Agric. Forest. Entomol., 8(1): $1-6$.

[84]. Oliveira, M. M. M. , Brugnera, D.F., Cardoso, M.G., Guimaraes, L.G.L., Piccoli, R.H. 2011. Rendimento, composição química e atividade antilisterial de óleos essenciais de espécies de Cymbopogon. Rev. Bras. Pl. Med., v. 13, p. 8-16.

[85]. Owayss, A.A. and Abd-Elgayed,A. A.2007. Potential Efficacy of Certain Plant Volatile Oils and Chemicals against Greater Wax Moth, Galleria mellonella L. (Lepidoptera: Pyralidae). Bull.Ent.Soc.Egypt,Econ.Ser.,No.33:67-75pp. 
[86]. Owusu, E. O. 2000. Effect of some Ghanaian plant components on control of two stored- product insect pests of cereals. Journal of Stored Products Research, Vol. 37, 1, 85-91.

[87]. Rajendran, S. and Sriranjini, V. 2008. Plant products as fumigants for stored-product insect control. Journal of Stored Products Research, 44: 126-35.

[88]. Regnault R. C. 1997. The potential of botanical essential oils for insect pest control. Integrated Pest Management Reviews, 2: 25 34.

[89]. Sallam, H.A., Elnagar, S., Ibrahim, S.M., 1991. Effects of gamma radiation on reproductive potential of the black cut worm, Agrotis ipsilion (Hufn.). Arab J. Nucl. Sci. Appl. 24, 165-174.

[90]. Salem, Nagwa, Y., Hoda, A. Ramadan and Elham, A. Sammour 2003. Physiological and histopathological effects of some wild plant extracts on the cotton leaf worm Spodoptera littoralis (BOISD) (Lepidoptera Noctuidae). Bull. Ent. Soc. Egypt, Econ., 29 (113).

[91]. Shishir-Tandon, Mittal, A. K., Kasana, V. K. and Pant, A. K. 2004. Effect of essential oil of Elsholtzia densa L. on growth and reproduction of Spilosoma obliqua (Walker). Indian J. Ent., 66(3): 206-208.

[92]. Tate, C. D., Carpenter, J.E., Bloem, S. 2007. Influence of radiation dose on the level of F1 sterility in the cactus moth, Cactoblastis cactorum (Lepidoptera: Pyralidae). Florida Entomologist 90: 537 - 544.

[93]. Tripathy, M. K., Singh, H. N. 2005. Synergistic effect of certain vegetable oils to the efficacy of synthetic pyrethroids for the control of Helicoverpa armigera (Hubner). Agric.Sci. Digest., 25(1): 1-5. 